\title{
Trends and insights of agroforestry practices in Madhya Pradesh, India
}

\author{
Arvind Bijalwan $^{1, *}$, Pooja Verma ${ }^{1}$, Manmohan J. R. Dobriyal ${ }^{2}$, A. K. Patil ${ }^{3}$, \\ Tarun Kumar Thakur ${ }^{4}$ and C. M. Sharma ${ }^{5}$ \\ ${ }^{1}$ Indian Institute of Forest Management, Nehru Nagar, Bhopal 462 003, India \\ ${ }^{2}$ Department of Silviculture and Agroforestry, College of Forestry, Navsari Agricultural University, Navsari 396450 , India \\ ${ }^{3}$ Madhya Pradesh Forest Department, Bhopal 462 004, India \\ ${ }^{4}$ Indira Gandhi National Tribal University, Amarkantak 484 887, India \\ ${ }^{5}$ College of Forestry, VCSG Uttarakhand University of Horticulture and Forestry, Hill Campus, Ranichauri, Tehri Garhwal 249 199, India
}

Agroforestry practices in Madhya Pradesh (MP), India existed in the primordial times, which can be evidenced almost in every region of the state; however, the pace of scientific inclusion in agroforestry and its extension is quite slow. There is lack of priority and limited work has been done related to agroforestry practices, possibly due to the presence of large natural forest area in the state. In the present context, to meet the national target of forest cover and to reduce pressure on nature forest, agroforestry seems to be a viable option as it provides a source of income for farming and tribal communities along with countless environmental benefits. This article provides a review and insight of agroforestry and extent of agriculture, horticulture and agroforestry in MP. It also provides information on diverse tree species under agroforestry systems, a mosaic of tree-crop combinations and horticulture species preferred by the farmers in different agro-climatic zones of the state. The authors have also tried to enlist the efforts of various government initiatives and other agencies involved in the extension of agroforestry in the state. The roles of MP Forest Department, MP Forest Development Corporation and allied Departments of the state in agroforestry and tree planting have also been discussed. Marketing of agroforestry produce, farmers' involvement in agroforestry practices and identification of key policy constraints of agroforestry in the state have been discussed and critically analysed.

Keywords: Agroforestry practices, agriculture, agroclimatic regions, horticulture.

AGROFORESTRY is a merger of agriculture crops and/or livestock with tree components on a unit piece of land with special arrangement of time and space. In Madhya Pradesh (MP), India, agroforestry is being practised in nearly every region of the state in the form of traditional agroforestry since time-immemorial. However, the exten-

*For correspondence. (e-mail: arvindbijalwan276@gmail.com) sion of agroforestry practices is slow in most of the regions. Traditionally, trees like babul, neem, shisham, teak, bamboo, palash, mahuwa, jamun, aonla, mango, guava, etc. are deliberately retained by farmers on their farm; however, some new entrants such as subabool (Leucaena leucocephala), Eucalyptus and khamair (Gmelina arborea) have also been adopted under agroforestry. Farmers were seen frequently growing paddy with babul (Acacia nilotica) under traditional agroforestry system ${ }^{1}$. The preference for babul is due to its robust nature, market accessibility, multiple products and services ${ }^{2}$. MP presently has $27.65 \%$ of forest and tree cover ${ }^{3}$, fairly better than other states of India; however, for attaining 33\% forest cover according to the Forest Policy 1988, it is imperative to promote trees outside forests (TOF) under agroforestry, farm forestry and social forestry. The total population of MP is 42.63 million, of which $72.37 \%$ is rural, including $21.09 \%$ tribal population ${ }^{4}$, whose potential can be harnessed for promotion of tree farming as a major economic activity to achieve the Sustainable Development Goals. Similarly, significant livestock population of the state can be properly managed through adoption of different silvipastoral and hortipastoral systems. With the increasing gap in demand and supply of forest produce in India from territorial forests, the role of agroforestry seems to be noteworthy in filling the gap. As far as agriculture in MP is concerned, it occupies a unique position with 11 agro-climatic regions and five cropping zones that grow all kinds of crops and a variety of cereals, pulses, oilseeds, fruits and vegetables. The state also occupies a special place for agricultural produce in the country. The farming sector in MP forms the mainstay of its economy and the primary source of employment for over $70 \%$ of its population. It contributes almost one-fourth of the gross state domestic product (GSDP) and about $60-75 \%$ of rural income ${ }^{5}$. In recent times, MP has received the Krishi Karman Award continuously for five years in succession for increased foodgrains production, thus proving the worth of agriculture in the state ${ }^{6}$. In 2015-16, the agriculture sector contributed around $34 \%$ of GSDP in $\mathrm{MP}^{7}$. 
Although MP has not been amongst the green revolution zones in the 1960s and 1970s, it has its own successful ventures in agriculture that exists with large tracts of traditional low technology and dryland farming areas ${ }^{8}$. Wheat, gram, rice, maize, cotton, rapeseed, mustard and arhar are the important foodgrain crops ${ }^{9}$. Among nonfood crops, oilseeds, particularly soybean, have played the leading role in the state ${ }^{10-12}$. Major commercial crops are cotton ${ }^{13}$ and sugarcane ${ }^{14,15}$ which are limited to some pockets. Wheat occupies the highest area under rabi season, and is mainly cultivated in Sehore, Vidisha, Raisen, Shivpuri, Gwalior, Ujjain, Hoshangabad, Sagar, Tikamgarh, Satna and Indore districts of the state. Paddy stands second in terms of area coverage and production ${ }^{16}$, and is mainly grown in the high rainfall and irrigated areas, viz. Balagahat, Seoni, Jabalpur, Damoh, Bhind, Morena and Shivpuri districts. There is excellent land-man ratio, good soil type, rich biodiversity, good support system of Primary Agriculture Cooperative Societies, agriculture mandis, state Agriculture Universities and Colleges, Krishi Vigyan Kendras (KVKs) and many government initiatives (projects/schemes, policies and subsidies) for farmers to boost agriculture production in the state.

\section{Agroforestry initiatives in Madhya Pradesh}

MP is the second largest state of India covering 9.5\% of the country's area. The state is endowed with rich natural resources, good climate and average rainfall, central location and fairly liberalized industrial policies, which make it favourable to set up agro-based and wood industries to process the wood raw material that may be produced in MP from agroforestry plantations. In April 1999, the MP government initiated a scheme to manage tree clad on private lands of the state in an effective manner called Lok Vaniki and later enacted as 'MP Lok Vaniki Adhiniyam 2001'. Plantations on private and revenue department wastelands, strengthening of panchayats, establishing other necessary institutions like 'Kisan Sangh' and 'Chartered Foresters' to manage forest-based activities besides tax collection in the non-Government sector are other dimensions of the Lok Vaniki initiative ${ }^{17}$. Initially, the scheme was employed in four districts, but now it covers 45 districts of the state ${ }^{18}$. Madhya Pradesh Forest Development Corporation (MPFDC) under its commercial plantation scheme has already undertaken plantation of trees such as teak and bamboo for industrial use. The involvement of paper and pulp industry for agroforestry is found beneficial for procurement of wood raw material security from agroforestry. Plantation carried out by some paper mills and other corporate houses are the sign of continuum in the wood utilization sector in the state. Similarly, for extraction of sandalwood oil and perfumery compounds there was promotion of commercial plantation of sandalwood in Katni district. A famous industrial group has also commenced and promoted tree plantation in various parts of $\mathrm{MP}^{19}$. Other companies also facilitated plantation of sandalwood on the farmlands of large farmers ${ }^{20}$. A famous corporate group is also involved in raising sandalwood plantation under medicinal and aromatic agroforestry $^{21}$.

Green programmes like farm forestry are found to be effective in many districts in MP, which supply fastgrowing, site-specific, improved quality pulpwood plantating stock, and provide economic support to small and marginal farmers through securing bank loans for plantations. The paper industry purchases the pulpwood at a pre-decided support price or the market price, whichever is higher at the time of harvest and also accelerates market linkage with farmers ${ }^{22}$. These private industries adopt buy-back system of marketing in which they provide planting material to farmers at a reasonable cost or free, and purchase after harvesting at prime prices/rates. In this manner, agroforestry practices also bring positive externalities through industrial boost for socio-economic and environmental benefits to local communities.

\section{Agroforestry systems in Madhya Pradesh}

Agroforestry systems vary in their structural complexity and species diversity, productive, protective attributes and socio-economic dimensions. Home-gardens/homesteads cultivation, and plantation-based agroforestry systems are found in the state. Trees in the farmlands are present in a scattered fashion and also on the farm boundaries for several benefits ranging from domestic use to soil conservation, or amelioration, etc. ${ }^{23}$. Agroforestry minimizes negative interactions in order to maximize the production of trees and crop components ${ }^{24}$. Different types of agroforestry systems such as agri-silviculture (AS), agri-horticulture (AH), silvi-pasture (SP), hortisilviculture (HS), boundary plantations (BP), etc. are commonly practised in MP to fulfil the multifunctional needs of local people. Horticulture-cum-fish culture and SP system also exits in the state ${ }^{25}$. Table 1 shows the diverse agroforestry systems in MP.

Table 1 reveals that majority of fruit and forest trees on farm exist as AS or AH, with wheat and paddy conventional crops. The farmer's eagerness for tree intervention in crop fields without much reduction in crop yield is a major factor that governs the adoption of agroforestry. The table also reveals that the farmer's inclination towards horticultural trees is more due to their economic worth and ready market availability in all regions of MP. The farmers in the state widely practise traditional agroforestry due to lack of information about the advantages of industrial agroforestry. They have a notion that crop productivity reduces under the trees, disregarding the increased overall productivity and additional services of agroforestry practices. Tree preference by farmers is 
REVIEW ARTICLES

Table 1. Agroforestry systems practised in Madhya Pradesh (MP), India

\begin{tabular}{|c|c|c|c|c|c|}
\hline Agroclimatic zones & $\begin{array}{l}\text { Major forest trees in } \\
\text { agroforestry }\end{array}$ & $\begin{array}{l}\text { Major fruit trees in } \\
\text { agroforestry }\end{array}$ & $\begin{array}{l}\text { Major agricultural } \\
\text { crops in } \\
\text { agroforetry }\end{array}$ & $\begin{array}{l}\text { Agroforestry } \\
\text { system }\end{array}$ & $\begin{array}{l}\text { Common agroforestry } \\
\text { combinations }\end{array}$ \\
\hline $\begin{array}{l}\text { Northern Hill region } \\
\text { of Chhattisgarh }\end{array}$ & $\begin{array}{l}\text { Babul, Khamer, } \\
\text { Subabul, Shisham, } \\
\text { Karanj }\end{array}$ & $\begin{array}{l}\text { Jamun, Guava, } \\
\text { Mango, Drumstick, } \\
\text { Aonla, Custard } \\
\text { Apple, Lemon, } \\
\text { Pear, Peach, } \\
\text { Litchi, Jackfruit }\end{array}$ & $\begin{array}{l}\text { Paddy, wheat, } \\
\text { maize, arhar, } \\
\text { moong, urad, } \\
\text { soyabean }\end{array}$ & $\mathrm{AS}, \mathrm{AH}$ & $\begin{array}{l}\text { Teak }+ \text { wheat/paddy, } \\
\text { teak }+ \text { soybean, paddy/wheat }+ \\
\text { babul, wheat }+ \text { guava, wheat }+ \\
\text { mango, paddy }+ \text { babul }\end{array}$ \\
\hline $\begin{array}{l}\text { Kymore Plateau and } \\
\text { Satpura Hills }\end{array}$ & $\begin{array}{l}\text { Babul, Khamer } \\
\text { Karanj, Teak, } \\
\text { Arjun, Mahua, } \\
\text { Palash, Shisham, } \\
\text { Sirish, Subabul, } \\
\text { Eucalyptus, } \\
\text { Bamboo }\end{array}$ & $\begin{array}{l}\text { Mango, Jamun, } \\
\text { Aonla, Guava, } \\
\text { Jackfruit, Lemon, } \\
\text { Ber }\end{array}$ & $\begin{array}{l}\text { Wheat, paddy, } \\
\text { gram, maize, } \\
\text { arhar, moong, } \\
\text { urad, masoor }\end{array}$ & $\mathrm{AS}, \mathrm{AH}$ & $\begin{array}{l}\text { Paddy/wheat }+ \text { babul, teak }+ \\
\text { wheat/paddy, wheat }+ \text { guava, } \\
\text { wheat }+ \text { khamer, wheat }+ \\
\text { mango, gram/wheat }+ \text { custard } \\
\text { apple, paddy }+ \text { shisham, } \\
\text { eucalyptus }+ \text { wheat, subabul }+ \\
\text { wheat }\end{array}$ \\
\hline $\begin{array}{l}\text { Central Narmada } \\
\text { Valley }\end{array}$ & $\begin{array}{l}\text { Shisham, Khamer, } \\
\text { Palash, Bamboo, } \\
\text { Mahua, Babul, } \\
\text { Subabul, Bamboo }\end{array}$ & $\begin{array}{l}\text { Mango, Jamun, } \\
\text { Ber, Guava, } \\
\text { Pomegranate, } \\
\text { Aonla, Ber, } \\
\text { Lemon, Mandarin, } \\
\text { Papaya }\end{array}$ & $\begin{array}{l}\text { Wheat, paddy, } \\
\text { gram, } \\
\text { soybean, } \\
\text { sugarcane, pea, } \\
\text { moong, urad, } \\
\text { arhar }\end{array}$ & $\mathrm{AS}, \mathrm{AH}$ & $\begin{array}{l}\text { Subabul }+ \text { wheat, sugarcane }+ \\
\text { babul, wheat }+ \text { khamer, } \\
\text { soybean }+ \text { bamboo }\end{array}$ \\
\hline Vindhya Plateau & $\begin{array}{l}\text { Babul, Shisham, } \\
\text { Neem, Khamer, } \\
\text { Mahua, Siris, } \\
\text { Subabul, Bamboo }\end{array}$ & $\begin{array}{l}\text { Guava, Ber, Lemon, } \\
\text { Aonla, Mosambi, } \\
\text { Mango, Chiku, } \\
\text { Papaya }\end{array}$ & $\begin{array}{l}\text { Paddy, wheat, } \\
\text { sugarcane, } \\
\text { maize, arhar, } \\
\text { gram, jowar }\end{array}$ & $\mathrm{AS}, \mathrm{AH}$ & $\begin{array}{l}\text { Paddy }+ \text { babul, shisham }+ \text { maize } \\
\text { guava }+ \text { wheat, guava }+ \text { paddy } \\
\text { babul }+ \text { soybean }\end{array}$ \\
\hline Gird Region & $\begin{array}{l}\text { Babul, Siris, } \\
\text { Shisham, Paalas, } \\
\text { Neem, Khejri, } \\
\text { Anjan, Tendu }\end{array}$ & $\begin{array}{l}\text { Ber, Karonda, } \\
\text { Custard Apple, } \\
\text { Pomegranate, } \\
\text { Bael, Aonla, } \\
\text { Guava }\end{array}$ & $\begin{array}{l}\text { Jwar, bajra, } \\
\text { mung, urad, } \\
\text { sessome, } \\
\text { sarson, arhar, } \\
\text { cotton }\end{array}$ & $\mathrm{AS}, \mathrm{AH}$ & $\begin{array}{l}\text { Babul }+ \text { jwar, mango + sarson, } \\
\text { shisham }+ \text { gram }\end{array}$ \\
\hline Bundelkhand Region & $\begin{array}{l}\text { Neem, Palash, } \\
\text { Shisham, Khair, } \\
\text { Karanj, Mahua, } \\
\text { Subabul }\end{array}$ & $\begin{array}{l}\text { Pomegranate, } \\
\text { Custard apple, } \\
\text { Aonla, Ber, Guava, } \\
\text { Orange, Chiku, } \\
\text { Mango, Mosambi, } \\
\text { Lime, Kraounda }\end{array}$ & $\begin{array}{l}\text { Jwar, maize, } \\
\text { mung, gram, } \\
\text { til, sarson, } \\
\text { wheat, arhar, } \\
\text { masoor }\end{array}$ & $\mathrm{AS}, \mathrm{AH}, \mathrm{SP}$ & $\begin{array}{l}\text { Neem }+ \text { wheat, shisam }+ \text { wheat, } \\
\text { palash }+ \text { sarson, custard apple }+ \\
\text { wheat }\end{array}$ \\
\hline Satpura Plateau & $\begin{array}{l}\text { Teak, Shisham, Sal, } \\
\text { Neem, Mahua, } \\
\text { Babul }\end{array}$ & $\begin{array}{l}\text { Pomegranate, } \\
\text { Orange, Papaya, } \\
\text { Mosambi, Guava, } \\
\text { Ber, Jamun, } \\
\text { Custard Apple, } \\
\text { Lemon, Mango, } \\
\text { Karonda }\end{array}$ & $\begin{array}{l}\text { Wheat, paddy, } \\
\text { jowar, bajara, } \\
\text { potato, urad, } \\
\text { gram, aarhar, } \\
\text { moong, } \\
\text { soyabean }\end{array}$ & $\mathrm{AS}, \mathrm{AH}$ & $\begin{array}{l}\text { Teak }+ \text { wheat, shisham }+ \text { wheat, } \\
\text { orange }+ \text { agriculture crops }\end{array}$ \\
\hline Malwa Plateau & $\begin{array}{l}\text { Suababul, Babul, } \\
\text { Neem, Khamer, } \\
\text { Shisham, Siris }\end{array}$ & $\begin{array}{l}\text { Lemon, Orange, } \\
\text { Aonla, Papaya, } \\
\text { Pomegranate, } \\
\text { Guava, Banana, } \\
\text { Mosambi, Chiku, } \\
\text { Grape, Ber }\end{array}$ & $\begin{array}{l}\text { Wheat, cotton, } \\
\text { arhar, moong, } \\
\text { urad, jwar, } \\
\text { bajra }\end{array}$ & $\mathrm{AS}, \mathrm{AH}$ & $\begin{array}{l}\text { Wheat }+ \text { khamer, wheat }+ \text { babul, } \\
\text { cotton }+ \text { neem }\end{array}$ \\
\hline Nimar Plains & $\begin{array}{l}\text { Shisham, Siris, Babul, } \\
\text { Subabul, Mahua, } \\
\text { Palash, Khamer }\end{array}$ & $\begin{array}{l}\text { Guava, Aonla, Lime, } \\
\text { Banana, Papaya, } \\
\text { Pomegranate, } \\
\text { Mango, Grape, } \\
\text { Chiku }\end{array}$ & $\begin{array}{l}\text { Wheat, arhar, } \\
\text { gram, cotton, } \\
\text { soybean, } \\
\text { moong, urad }\end{array}$ & $\mathrm{AS}, \mathrm{AH}$ & Wheat + mahua, shisham + wheat \\
\hline Jhabua Hills & $\begin{array}{l}\text { Mahua, Tadi, Palash, } \\
\text { Siris, Babul, } \\
\text { Subabul, Neem, } \\
\text { Khejri, Shisham }\end{array}$ & $\begin{array}{l}\text { Aonla, Guava, Ber, } \\
\text { Pomegranate, } \\
\text { Mango, Karaunda }\end{array}$ & $\begin{array}{l}\text { Wheat, maize, } \\
\text { urad, gram, sar- } \\
\text { son, groundnut, } \\
\text { moong, mustard }\end{array}$ & $\mathrm{AS}, \mathrm{AH}$ & $\begin{array}{l}\text { Wheat }+ \text { babul, wheat }+ \text { tadi, } \\
\text { neem }+ \text { wheat }\end{array}$ \\
\hline
\end{tabular}

AS, Agrisilviculture; AH, Agrihorticulature; SP, Silvipasture. 
determined by financial gains, growing markets and domestic needs. The traditional agroforestry practised by the farmers of the state, does not contribute much to their livelihoods in terms of monetary benefits. Nevertheless, the multifaceted benefits of agroforestry practices such as livelihood security, environmental services and food security cannot be ignored. Babul (Acacia nilotica), neem (Azadirachta indica), subabul (Leucaena leucocephala), bamboo and khamar are the common trees widely retained in the farmlands because of their multifarious uses and benefits. These trees contribute to traditional medicines, in situ conservation, habitat for pollinators, improving the environment, maintaining tree species richness in the farm landscape and also offer a habitat for biodiversity. Babul trees are gregariously present in the state due to their self-generating and vigorous nature; they also provide multiple products, e.g. tannins, gums, timber, fuel, fodder and medicine, etc. Neem is also retained for fuelwood, insecticide, neem cakes, medicinal and other agricultural uses. Subabul and khamer are also seen in the farms, as they are multipurpose trees used for a variety of purposes such as furniture, firewood, fibre, and leaves as fodder for livestock. Subabul, though exotic but well adapted in India, is considered as an excellent source of high-protein fodder. Bamboo also plays an important role in enhancing the livelihood of the rural community in the state, as it has the ability to survive in varied edaho-climatic conditions. It is also an excellent alternative to wood, and is used in construction as well as paper and pulp industries.

\section{Acceptability of trees under agroforestry}

The farmers integrate a variety of tree components in their croplands and livestock production depending upon the varied agro-climates and local needs. The trees which are commonly grown under agroforestry in MP are $A c a-$ cia nilotica, Azadirachta indica, Zizyphus mauritiana, Butea monosperma, Syzygium cumini, Tectona grandis, Dalbergia sissoo, Eucalyptus, Acacia leucophloea, Casuarina equisetifolia, subabul, Pithocellobium dulce, Ailantus exelsa, Prosopis cineraria, Aegle marmelos, Albizia lebbeck, bamboo and Emblica offcinalis ${ }^{26}$. A. nilotica (babul) is frequently found in several districts of the state $^{27,28}$. It also grows around homesteads, along roadsides and is found scattered in the agricultural farmlands ${ }^{29}$. Albizia procera is another promising tree species found in the state under agroforestry and community forestry ${ }^{30}$. Plumeria (Plumeria acutifolia) and peepal (Ficus religiosa) are nurtured/retained for religious purposes, and for shade in temples and farmlands. Trees such as eucalyptus and bamboo are occasionally grown for construction materials; neem ( $A$. indica) is grown for medicinal purposes, construction and shade ${ }^{31}$. Bamboo is also a significant forest produce being used as a livelih- ood option by forest-dependent people of the state ${ }^{32,33}$. The potential fruit and vegetable cultivation belts in MP are Bhopal, Betul, Hoshangabad, Sagar, Jabalpur, Chhindwara, Ujjain, Shajapur, Mandsour, Ratlam, Dewas, Indore, Dhar, Jhabua, Khargone and Khandwa districts $^{34}$. The important fruits include mango, chiku, guava, lime, banana, papaya, aonla, ber, pomegranate, jackfruit, pear and peach ${ }^{35}$. Aonla (E. officinalis) is considered as an ideal option among the semiarid, arid and rainfed areas of the state ${ }^{36,37}$. The efficient utilization of farmlands by integration of horticulture trees generates adequate income, provides employment and improves livelihood $^{38}$; it is also environment-friendly compared to traditional farming practices. Therefore, incorporation of horticulture trees can be a viable option for small and marginal farmers of the state.

Agroforestry emerges as an effective tool for improvement of rural economy due to low investment, high profitability and high income-generating practices ${ }^{39}$. Numerous agroforestry systems and combinations are practised by the farming community in MP (Table 2). Table 2 shows that many multipurpose trees are found compatible in various regions of the state. According to the studies listed, we can interpret that crops such as wheat, paddy, medicinal plants, vegetables, etc. under trees not only increase the overall productivity, but also their rate of survival and yield was better. Trees like babul, bamboo, shesham, aonla, teak, etc. are among the most suitable in the state, which can be grown under agroforestry with minimal crop yield reduction. Appropriate tree-crop arrangements can indicate which combination is better in terms of profitability and act as a feasible option which provides livelihood security to the rural community with less supervision and inputs. These agroforestry combinations and systems help increase the economy of farmers, provide food security and make them self-sufficient. The ecosystem services generated from agroforestry adoption will help ameliorate the micro climate of farmlands to promote climate-resilient crops. These agroforests will be an effective tool for climate mitigation and adaption mechanism to counter climate change, and act as a sink for greenhouse gases. If systematically inventoried and documented, the pool carbon credits from village grid can be sold in the market to give additional economic benefits to farmers for retaining trees on farms ${ }^{40}$. The soil and water relationship under agroforests compared to sole crop is better for water use efficiency, nutrient uptake and soil conservation. Agroforestry expansion in MP can be a better alternative for forest produce from farms which can reduce the pressure on natural forests. The Central government has directed all the states to change the forest produce, timber felling and transit rules for farm-grown trees to ease the tree felling operation and minimize the pressure on natural forest. Further, recently, bamboo has been denotified by the central government as timber under the Indian Forest 
REVIEW ARTICLES

Table 2. Review of agroforestry studies in MP

\begin{tabular}{|c|c|c|}
\hline Agroforestry components & Outcome of the study & Regions/districts \\
\hline Acacia nilotica with rice & $\begin{array}{l}\text { The tree crown reduces the intensity of light by } 8.5 \text { times at } 2 \mathrm{~m} \\
\text { and } 1.6 \% \text { at } 8 \mathrm{~m} \text { distance from the tree base. The yield of paddy } \\
\text { was lowest }\left(339 \mathrm{~g} / \mathrm{m}^{2}\right) \text { at } 2 \mathrm{~m} \text { and highest }\left(606 \mathrm{~g} / \mathrm{m}^{2}\right) \text { at } 25 \mathrm{~m} \\
\text { distance from the tree trunk. }\end{array}$ & $\begin{array}{l}\text { Sub-humid tropical } \\
\text { region of } \mathrm{MP}^{51}\end{array}$ \\
\hline Acacia nilotica with rice & $\begin{array}{l}\text { Tree canopy management with different pruning intensity of trees } \\
\text { on farm bunds not only improves light penetration, but also in- } \\
\text { creases wheat and paddy yield. The optimum yield was obtained } \\
\text { under } 40 \% \text { canopy pruning intensity. }\end{array}$ & $\begin{array}{l}\text { Jabalpur, Katni, } \\
\text { Maihar, Satna, } \\
\text { Rewa }^{52}\end{array}$ \\
\hline $\begin{array}{l}\text { Bamboo-based agroforestry system with crops: } \\
\text { Glycine max, Guizotia abyssinica, Phaseolus } \\
\text { aureus, Brassica campestris, Triticum } \\
\text { aestivum, Phaseolus mungo and Cajanus cajan }\end{array}$ & $\begin{array}{l}\text { Bamboo based agro-forestry models for degraded farmland } \\
\text { reclamations. There was considerable increase in the number of } \\
\text { species, diversity index and species richness at agroforestry } \\
\text { sites compared with control. }\end{array}$ & Jabalpur $^{53}$ \\
\hline $\begin{array}{l}\text { Medicinal agroforestry (Rauvolfia serpentina, } \\
\text { Curcuma aromatica, Chlorophytum } \\
\text { arundinaceum, Curculigo orchioides were } \\
\text { planted under Acacia auriculiformis, Eucalyp- } \\
\text { tus hybrid, Albizia lebbeck, Albizia procera, } \\
\text { Gmelina arborea, Melia azedarach, } \\
\text { Pongamia pinnata, Leucaena leucocephala) }\end{array}$ & $\begin{array}{l}\text { Best survival and yields were under } E \text {. tereticornis, A. auriculi- } \\
\text { formis and L. leucocephala and poorest under } M . \text { azedarach and } \\
P . \text { pinnata. Survial was lowest in } R \text {. serpentine and highest in } \\
\text { C. orchioides. }\end{array}$ & Bilaspur $^{54}$ \\
\hline $\begin{array}{l}\text { Dalbergia sisso, Tectona grandis, } \\
\text { Mangifera indica, Psidium guajava, } \\
\text { Albizia procera-based agroforestry }\end{array}$ & $\begin{array}{l}\text { Growth and performance of } D \text {. sisso was better than other tree } \\
\text { species. It performed better in respect of height }(248.2 \mathrm{~cm}) \text { and } \\
\text { diameter }(4.32 \mathrm{~cm}) \text { followed by } T \text {. grandis, } M \text {. indica and } \\
\text { P. guajava. }\end{array}$ & Jabalpur $^{55}$ \\
\hline $\begin{array}{l}\text { Silviolericultural system comprises of: MPTS - } \\
\text { Acacia nilotica, Albizia procera, Dalbergia } \\
\text { sissoo, Gmelina arborea, Tectona grandis; } \\
\text { Vegetables crop - Lycopersicum esculentum, } \\
\text { Solanum melongena, Vigna sinensis, } \\
\text { Abelmoschus esculentus, Raphanus sativus, } \\
\text { Spinacia oleracea }\end{array}$ & $\begin{array}{l}\text { Best performance of vegetables during the three seasons was under } \\
\text { A. nilotica, followed by } A \text {. procera. Lower yield was under } \\
T \text {. grandis and G. arborea. Yield of vegetables under trees was } \\
\text { significantly higher than sole vegetable crop (control). }\end{array}$ & Jabalpur $^{56}$ \\
\hline $\begin{array}{l}\text { Teak agroforestry systems with agricultural crops } \\
\text { include wheat, gram, ashwagandha, wild oats } \\
\text { and barley }\end{array}$ & $\begin{array}{l}\text { Annual carbon stock gain in teak in different agroforestry systems } \\
\text { was in the order teak-barley }(60.47 \%)>\text { teak-wheat } \\
(56.92 \%)>\text { teak-wild oats }(54.94 \%)>\text { teak-gram }(37.15 \%)> \\
\text { teak-ashwagandha }(11.86 \%) \text {. }\end{array}$ & Jabalpur $^{58}$ \\
\hline $\begin{array}{l}\text { Subabul, papaya, babul, guava, teak, Eucalyptus, } \\
\text { butea, with various cereal and vegetable crops }\end{array}$ & $\begin{array}{l}\text { Multiple plantations pattern of the five species crop geometry } \\
\text { agroforestry system is beneficial to farmers of this area even } \\
\text { with small land holdings, to improve their economic status. }\end{array}$ & Sagar $^{59}$ \\
\hline
\end{tabular}

Act (1927), exempting it from timber felling and transit rules when grown outside the forest areas with a view to easily harvest the bamboo without legal hurdle and meet the requirement.

\section{Programmes and schemes related to agroforestry}

In post social forestry regime MP has formulated statewide farm forestry strategy which incorporates planting of tree on bunds and water conservation areas. In 1991, the state introduced the Joint Forest Management (JFM) scheme in Harda division. Now JFM has spread all over in MP to manage the forestry activity in forests and public land with peoples' participation. In 1982, the
Directorate of Horticulture and Farm Forestry, Government of MP was set-up for the production of horticultural crops and to promote agro-based industries. The Narmada-Malwa-Gambhir link project of MP was also launched to improve green cover in the area. Moreover, tree plantation under the Sardar Sarovar Scheme with financial assistance of NVDA (Narmada Valley Development Authority), MP, for tree planting on bunds and community plantations in 185 villages in Dhar, Jhabua and Khargon districts has been completed. The MP government has implemented many new schemes, projects and extension activities from time to time to encourage farmers to practice agroforestry. In 2013, 'Kisan Laxmi Yojana' scheme was launched in which farmers who are 
interested in planting trees on their farmlands will be provided incentives for three years, provided $70 \%$ of trees survive after two years. The state government, private agencies, NGOs and wood-based industries have taken several initiatives in extension programmes, effectual promotion and marketing of agroforestry produce. Another scheme titled 'Niji Bhoomi Par Vriksharopan Protsahan Yojna' (promotion of tree plantation on private lands) with the objective to make farmers aware and to promote plantation on private lands was also launched. Plantations on private land reduce the pressure on notified forests along with conserving soil and water.

In 2016, the government of MP came up with an ambitious plan for doubling the income of farmers in five years by keeping one-third of the farmlands under innovative traditional farming, one-third of the area under agroforestry/agro-horticulture and rest one-third of the area under animal husbandry. It is essential that agriculture and other components related to it such as animal husbandry, horticulture, fisheries, dairy, lac culture, sericulture, etc. should be linked. Promoting the cultivation of flowers, medicinal and aromatic plants, and bamboo at the commercial level to contribute towards poverty alleviation and subsistence income for the rural poor is the way forward. A target of 10 lakh ha of land under agroforestry in the next five years is planned in the state.

In recent times, the Government of India has launched the Sub-mission on Agroforestry under the National Mission for Sustainable Agriculture (one of the missions under the National Action Plan for Climate Change) with Rs 50 crore in 2016-17 and Rs 100 crores in 2017-18. MP is among the first eight states (the others are Gujarat, Himachal Pradesh, Haryana, Punjab, Tamil Nadu, Andhra Pradesh and Karnataka) where the mission started in 2016 with budget expenditure of Rs 420 lakhs till December 2016 (following Gujarat with Rs 450 lakhs) due to its relaxed harvesting and timber transit rules for promotion of agroforestry ${ }^{41}$. In tune with the National Agroforestry Policy 2014, the government of MP is planning to come up with its State Agroforestry Policy. In 2016, the Research, Extension and Lok Vaniki Division of the Forest Department of MP, launched a scheme for the welfare of farmers ('Krishivaniki Se Krishak Samridhi Yojna') for the promotion of agroforestry in the state, with initial financial support from Compensatory Afforestation Fund Management and Planning Authority (CAMPA). Under this scheme, planting materials are to be given free of cost to the farmers, and incentives may also be given according to the survival of the plants. The target for plantation of 130 lakh plants has been fixed in different forest circles of MP during 2017 by the Forest Department (Figure 1) $)^{42}$.

In addition, many private agencies and NGOs are involved in agroforestry promotion in MP for environment-friendly, sustainable management of natural resources, promotion and advocating low carbon pathways, development of research and technology, and efficient marketing of produce.

\section{Marketing strategy for agroforestry produces and role of MPFDC}

Forest/tree produce in MP are categorized in three groups, viz. timber, fuelwood and bamboo. The nationalized minor forest produce in the state include tendu leaf, sal seed and kullu gum and the non-nationalized minor forest products are harra, all other gums, satawar, kalmegh, giloe, bark, etc. with more than 155 products $^{43}$. The marketing of forest products like timber, poles, fuelwood, bamboo, etc. is being done through auction in commercial depots and by sale on notified rates in the nistar depots. The marketing of nationalized products like tendu leaves in the state adopts a three-tier systems consisting of primary forest produce cooperative societies, district primary forest produce cooperative unions and MPSMFCF (MP State Minor Forest Produce (Trade and Development) Cooperative Federation). The villagers are free to collect and sell the produce, usually after fulfiling their own needs; the villagers vend the remaining produce to small local traders or middlemen at minimal rates. The Federation gathers information about market price and supply conditions, and transfers this to the district unions so that the produce collected by the societies can be suitably sold at remunerative prices ${ }^{44}$. This type of mechanism has to be undertaken for agroforestry produce in the state for rational pricing and marketing. In recent times, several industries (paper, cottage, biofuel, lac, etc.) are also involved in marketing of agroforestry produce in MP. The industries follow buy-back mechanism of marketing through which farmers get assured market for their produce and also get the best-quality planting materials. These industrial approaches influence/motivate the farmers to adopt agroforestry practices on a large scale.

The mission of MPFDC is to supplement the Forest Department in enriching the tree cover of the state along

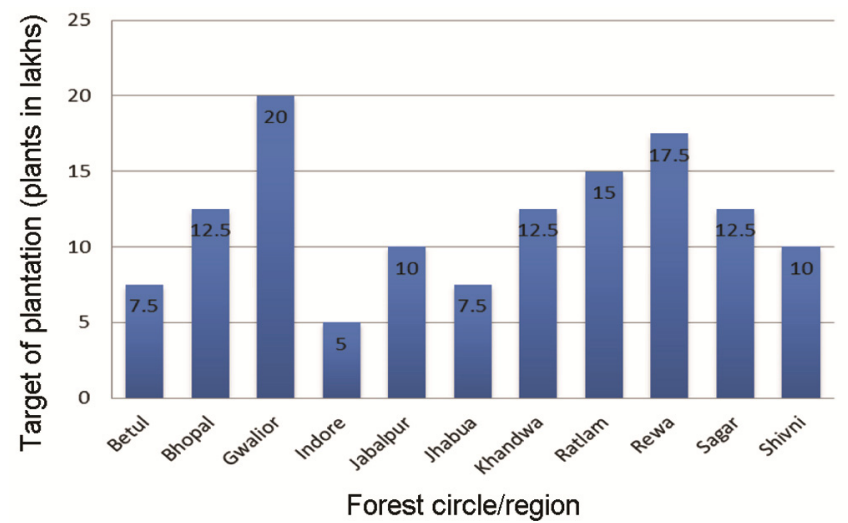

Figure 1. Target for plantation under 'Krishivaniki Se Krishak Samridhi Yojna' in Madhya Pradesh (MP), India. 
with improvement in the socio-economic conditions of people adjoining forest areas ${ }^{45}$. The PPP (private-public partnership) in agroforestry is also taking momentum in MP, with a view that the harvest from a farm is to be supplied to the industry at the market rate and buy-back guarantee $^{46}$. MPFDC also identifies appropriate farmlands for plantations, and improvement of interface between farmers and industries for better market linkage.

\section{Education, research and extension in agroforestry}

MP has got vast potential to develop diversified agroforestry systems/models. Successful agroforestry models have already been adopted in different parts of the states like bamboo-based agroforestry models, agri-silviculture models, horti-aqua models, etc. MP has numerous education and research institutions, KVKs and Van Vigyan Kendras (VVKs) for the development of agriculture and agroforestry. Extension services are important, and are delivered through KVK with the help of specialists in agroforestry for smooth dissemination of successful agroforestry models ${ }^{26}$. Education, research and extension activities influence the farmers to adopt agroforestry on their farmlands. The state has several universities, colleges and institutes dealing with agriculture and agroforestry issues. Private institutions, industries and CSR cell of the corporate sector in MP also impart training and extension for expansion of agroforestry. These institutions and universities help in educating the people and expanding the horizons of agroforestry in a sustainable manner in the state. Poverty alleviation is not possible without modernization of the agriculture and forestry sector. Poverty alleviation, sustainable forest management, and sustainable agriculture and livestock management are interlinked ${ }^{47}$. Hence growing trees on farmlands results in economic, social and environmental benefits for the land users ${ }^{48}$.

\section{Possibility and challenges in agroforestry}

Integrated farming practices are more substantial, efficient and feasible for small and marginal farmers in MP. A variety of tree-crop combinations are followed by the farmers according to their needs and variability in the agro-climatic zones of the state. Multipurpose woody perennials are the choice to integrate with agricultural crops/vegetables/medicinal plants or with grasses. AS, $\mathrm{AH}$ and SP systems are found to be common in the state. Usually, lack of scientific knowledge, institutional approach and negative attributes of tree component (viz. long rotation, shade effect, allelopathy and large canopy) compel farmers to avoid adopting tree components in their fields. However, in recent years climatic aberration, and increase in population and decrease in the size of agricultural land holdings has generated, interest among farmers to adopt agroforestry. To overcome the uncertainty of the monsoon and frequent natural calamities and to maintain food security, the farmers adopt a sustainable land-use system ${ }^{49}$ which has diversified outputs; sustained agriculture productivity and diverse income. At present, agroforestry is being practised and adopted by farmers in different agro-climatic zones based on the local needs and market conditions of produce, periodic estimation and monitoring of the area under it; however, it is still a challenging task due to lack of uniform methodology adopted by the different agencies. The present probable area under agroforestry in India is estimated to be $25.32 \mathrm{~m}$ ha, or $8.2 \%$ of the total geographical area of the country ${ }^{50}$. However, Forest Survey of India, 2013 estimated the area under agroforestry in the country as $11.54 \mathrm{~m}$ ha, which is $3.39 \%$ of the geographical area of India; and in MP it is only $0.67 \mathrm{~m}$ ha, which is $2.19 \%$ of the total geographical area of the state. Despite encouragement for growing trees on farmlands, the farmers of MP have to deal with many constraints and limitations related to agroforestry. The difficulty in felling, harvesting, transit pass and marketing (rights on cutting and selling of wood), and insecure regulation discourage farmers to cultivate trees ${ }^{51}$. Likewise, there are several other issues/ factors influencing adoption of agroforestry in the state (Figure 2). Farmers practising sole agriculture/monoculture suffer from increase in minimum support price (MSP), mounting debt, loan problems; and the monsoondependent nature of the agriculture sector continues to pose a major problem for the agrarian community (majorly small and marginal farmers) in the state. Agroforestry is the most economical, sustainable and stable alternative for ecological security of land production system; but it is not getting the expected momentum in MP.

\section{Conclusion}

The rapid growth in population, declining size of land holdings and irregular weather conditions are increasing the pressure on cultivation of sole agriculture crops. In MP, most of the farmers having small and marginal land holding are not able to fulfil their basic and multifunctional needs from sole agriculture crops. To mitigate these situations, suitable institutional approach, research and extension activities need to be carried out in the state, to encourage the farmers to adopt sustainable land-use practices and integrated farming practices, viz. agroforestry. Incorporation of trees/livestock within the farmlands will generate adequate income and employment for the small and marginal farmers. Madhya Pradesh Forest and Agriculture Department, and NGOs in collaboration with private wood-based industries are promoting agroforestry and farm forestry at a large scale in the state. These initiatives will not only fulfil the domestic and economic 


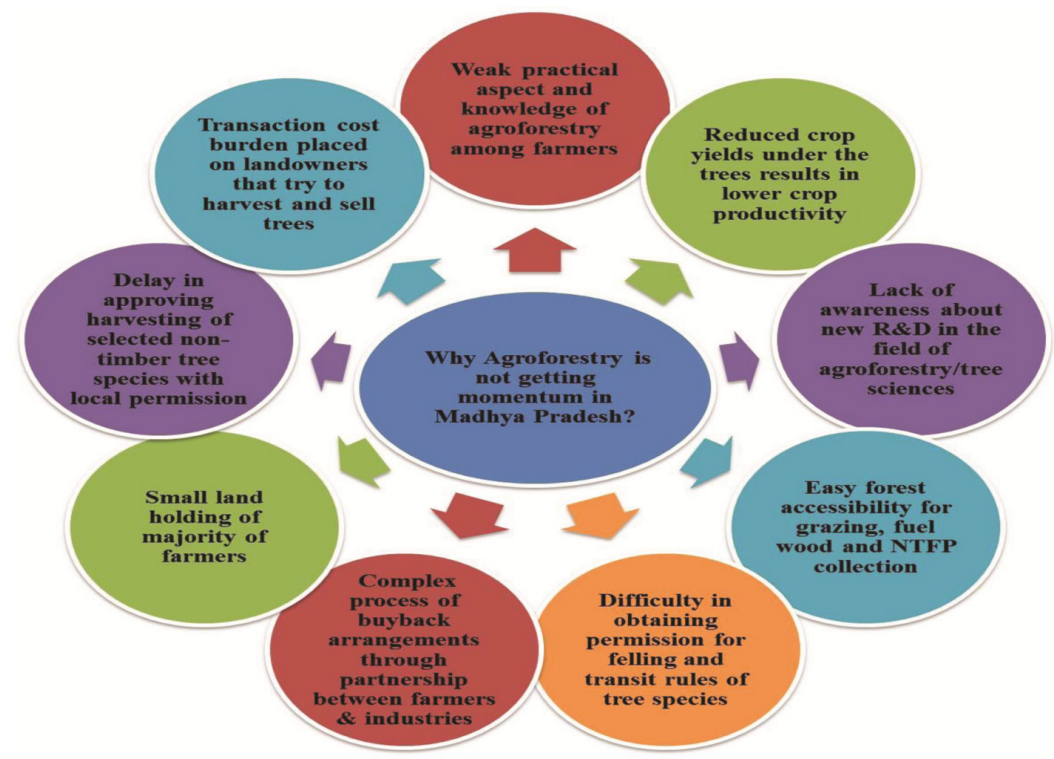

Figure 2. Pictorial representation showing the factors influencing adoption of agroforestry among farmers in MP.

needs of the farmers, but also provide several environmental benefits. Planting trees and shrubs on agricultural lands will also lessen the rate of NTFP extractions from the forests, and hence reduce the pressure on the forests. We hope that according to the guidelines of National Agroforestry Policy (2014), the inception of State Agroforestry Policy and Sub-mission on Agroforestry under NMSA, farmers will cultivate trees on their lands for wood and food security. Further, agroforestry practices are an important, efficient and viable option for MP to maintain its forest resources and agrarian identity at the national level.

1. Viswanath, S., Kaushik, P. K., Pandey, D. K. and Amit, S., Effect of A. nilotica on rainfed rice crop in Chhattisgarh, Madhy Pradesh. Ann. For., 1998, 6(1), 103-109.

2. Viswanath, S., Nair, P. K. R., Kaushik, P. K. and Prakasam, U., Acacia nilotica trees in rice fields: a traditional agroforestry system in central India. Agrofor. Syst., 2000, 50(2), 157-177.

3. FSI, India State of Forest Report, Forest Survey of India, Dehradun, 2015.

4. Census 2011, Ministry of Home Affairs, Government of India (GoI), 2011.

5. http://www.mp.gov.in/unlimited-potential-in-agriculture

6. http://timesofindia.indiatimes.com/city/bhopal/M-P-bags-award-for4th-year-2-farmers-to-get-Krishi-KarmanAward/articleshow/50673411.cms

7. http://www.prsindia.org/administrator/uploads/general/148903306 1 MP\%20Budget $\% 202017-18$.pdf

8. Madhya Pradesh Development Report/Planning Commission, Agriculture in Madhya Pradesh, 2009.

9. DES, A report on assessment of marketable and marketed surplus of wheat, gram and tur in Madhya Pradesh, Directorate of Economics and Statistics, Ministry of Agriculture, GoI, 2014; http://jnkvv.org/PDF/AERC/Study-110.pdf

10. Lal, M., Singh, K. K., Srinivasan, G., Rathore, L. S., Naidu, D. and Tripathi, C. N., Growth and yield responses of soybean in
Madhya Pradesh, India to climate variability and change. Agric. For. Meteorol., 1999, 93(1), 53-70.

11. De, D., Singh, R. S. and Chandra, H., Technological impact on energy consumption in rainfed soybean cultivation in Madhya Pradesh. Appl. Energy, 2001, 70(3), 193-213.

12. Mandal, K. G., Saha, K. P., Ghosh, P. K., Hati, K. M. and Bandyopadhyay, K. K., Bioenergy and economic analysis of soybeanbased crop production systems in central India. Biomass Bioenergy, 2002, 23(5), 337-345.

13. Kaushik, V. K., Rathore, V. S. and Sood, N. K., Incidence of bollworms and losses caused to cotton in Madhya Pradesh, 1969, 31, 175-177.

14. Kannan, S., Problems of iron deficiency in different crop plants in India: causative factors and control measures. J. Plant Nutr., 1984, 7(1-5), 187-200.

15. Chouhan, S., Singh, S. R. K., Pande, A. K. and Gautam, U. S., Adoption dynamics of improved sugarcane cultivation in Madhya Pradesh. Indian Res. J. Extens. Educ., 2016, 13(2), 26-30.

16. www.indianetzone.com

17. Bhattacharya, A. K. and Basnyat, B., Lok Vanaki - a recent innovative approach for managing private forestry in Madhya Pradesh, India. Banko Janakari, 2005, 15(2), 24-27.

18. mpforest.org/lokvaniki.html

19. http://www.business-standard.com/article/markets/corporatesector-enters-sandalwood-plantation-111040800086_1.html

20. http://www.mpsfdc.com/Workshop $\% 20$ Proceeding.pdf

21. http://www.dsgroup.com/agro-forestry.aspx

22. http://bilttreetech.com/about-history.asp

23. Tewari, S. K., Agro-forestry Project; Department of Genetics and Plant Breeding, College of Agriculture, G.B. Pant University of Agriculture and Technology Pantnagar 263145 (14-1-2008), 2008 .

24. Bleasdale, J. K. A., The relationship between the weight of a plant part and total weight as affected by plant density. J. Hortic. Sci., 1967, 42(1), 51-58.

25. Gupta, N., Singh, M. and Sharma, R. P., Evaluation of integrated horticulture-cum-fish farming in Malwa Region of Madhya Pradesh, India. Curr. World Environ., 2015, 10(2), 667.

26. Chavan, S. B., Keerthika, A., Dhyani, S. K., Handa, A. K., Newaj, R. and Rajarajan, K., National Agroforestry Policy in India: a low hanging fruit. Curr. Sci., 2015, 108(10), 1826. 
27. Anis, M., Sharma, M. P. and Iqbal, M., Herbal ethnomedicine of the Gwalior forest division in Madhya Pradesh, India. Pharma. Biol., 2000, 38(4), 241-253.

28. Ginwal, H. S. and Gera, M., Genetic variation in seed germination and growth performance of 12 Acacia nilotica provenances in India. J. Trop. For. Sci., 2000, 12(2), 286-297.

29. Pandey, C. B., Singh, A. K. and Sharma, D. K., Soil properties under Acacia nilotica trees in a traditional agroforestry system in central India. Agrofor. Syst., 2000, 49(1), 53-61.

30. Roychoudhury, N., Chawhaan, P. H., Mandal, A. K. and Joshi, K. C., Genetic analysis of infestation of borer, Bruchus bilineatopygus Pic. (Coleoptera: Bruchidae), in seeds of Albizia procera (Roxb.) Benth. J. Trop. For., 2010, 26(2), 63-71.

31. Brodt, S. B., Interactions of formal and informal knowledge systems in village-based tree management in central India. Agric. Hum. Values, 1999, 16(4), 355-363.

32. Jamatia, S., Livelihood of the bamboo base: challenges and opportunities. In Proceedings of 54th Society of Wood Science and Technology Conference on Sustainable Development of Wood and Biomass in our New Global Economy, International Bamboo and Rattan, Beijing China, 2012, vol. 20, pp. 1-16.

33. Kumar, R. S., Binu, N. K., Nishant, N., Buxy, S. and Sinha, G. N., A review of bamboo based agroforestry models developed in different parts of India, productivity and marketing aspects, 2014, pp. $45-52$.

34. NHMAPMP: National Horticulture Mission, Action Plan for Madhya Pradesh, A report prepared by Rabo India Finance Private Limited, New Delhi, 2005.

35. http://www.mphorticulture.gov.in/agri climatic.php

36. Prasad, R., Pandey, A. K., Newaj, R., Dhyani, S. K., Saroj, N. K. and Tripathi, V. D., Risk and vulnerability due to climate change and adaptation initiatives for agricultural resilience in Panna district of Madhya Pradesh, central India. Range Manage. Agrofor., 2014, 35(1), 157-162.

37. Pandey, D., Pandey, G. and Tripathi, M., Variability in aonla (Emblica officinalis Gaertn.) accessions collected from Madhya Pradesh. Prog. Hortic., 2014, 46(2), 280-284.

38. Gill, M. S., Singh, J. P. and Gangwar, K. S., Integrated farming system and agriculture sustainability. Indian J. Agron., 2010, 54(2), 128-139.

39. Current, D., Lutz, E. and Scherr, S. J., The costs and benefits of agroforestry to farmers. World Bank Res. Observ., 1995, 10(2), $151-180$.

40. Dobriyal, M. J., Dashora, L. K., Maloo, S. R. and Sarolia, D., Improvement in livelihoods and benefits of small and marginal farmers through agroforestry interventions with carbon finance. In Proceedings of National Seminar on Agroforestry: an Evergreen Agriculture for Food Security and Environmental Resilience, Navsari Agricultural University, Navsari, 2-4 February 2012, pp. 201211

41. MoA\&FW, New steps, Progressive steps - a glimpse of achievement during June 2014 to December 2016, p. 27; ww.icar. org.in/E-Book/2016/English/index.htmlw, 2017.

42. Forest Department of MP, Research, Extension and Lok Vaniki, Krishi Vaniki se Krishak Samiridhi Yojana, 2016.
43. http://mpbusinessline.com/SectorDetails.aspx?authkey=N4UGMicYTfc=

44. http://planningcommission.nic.in/plans/stateplan/sdr/sdr_mp1909. pdf

45. MPFD, Madhya Pradesh Forestry Action Plan, Madhya Pradesh Forest Department, Bhopal, 1999.

46. MPFDC, Proceedings Consultative Workshop on PPP-based Farm Forestry, MP State Forest Development Corporation, 30 April 2013.

47. Pandey, D. N., Multifunctional Agroforestry system in India for livelihoods: current knowledge and future challenges (no. id: 204), 2005.

48. Lasco, R. D., Delfino, R. J. P., Catacutan, D. C., Simelton, E. S. and Wilson, D. M., Climate risk adaptation by smallholder farmers: the roles of trees and agroforestry. Curr. Opin. Environ. Sustain., 2014, 6, 83-88.

49. Dhyani, S. K., National Agroforestry Policy 2014 and the need for area estimation under agroforestry. Curr. Sci., 2014, 107(1), 9-10.

50. Chambers, R. and Leach, M., Trees as savings and security for the rural poor. World Dev., 1989, 17(3), 329-342.

51. Pandey, C. B., Pandya, K. S., Pandey, D. and Sharma, R. B. Growth and productivity of rice (Oryza sativa) as affected by Acacia nilotica in a traditional agroforestry system. Trop. Ecol., 1999, 40(1), 109-117.

52. Upadhyaya, S. D., Nema, S. and Bhargava, M. K., Agroforestry practices for food-fuel security in rainfed agro-ecosystem: a management option. Indian J. Agrofor., 2008, 10(1), 15-18.

53. Behari, B., Aggarwal, R., Singh, A. K. and Banerjee, S. K., Vegetation development in a degraded area under bamboo based agroforestry system. Indian For., 2000, 126(7), 710-720.

54. Chadhar, S. K. and Sharma, M. C., Survival and yield of four medicinal plant species grown under tree plantations of bhataland. Vaniki Sandesh, 1996, 20(4), 3-5.

55. Singh, R., Pal, R. S. and Banerjee, S., Growth performance of multipurpose tree species in degraded land under agroforestry practices. J. Trop. Forestry, 2009, 25(1/2), 24-29.

56. Khatri, N. and Reddy, G. R. S., Performance of multipurpose tree species in a Silvi-Olericultural system in India. In Proceedings of the National Workshop, Pune, India, 6-9 April 1994, pp. 47-50.

57. Chadhar, S. K., Six years of extension and research activities in Social Forestry Division, Jhabua (MP). Vaniki Sandesh, 2001, 25(4), 6-10.

58. Jain, A. and Ansari, S. A., Quantification by allometric equations of carbon sequestered by Tectona grandis in different agroforestry systems. J. For. Res., 2013, 24(4), 699-702.

59. Hymavathi, H. N., Kandya, A. K. and Patel, L. P., Beneficial effects of multiple plantation patterns in agroforestry systems. Indian For., 2010, 136(4), 465-475.

Received 22 May 2017; revised accepted 27 May 2019

doi: $10.18520 / \mathrm{cs} / \mathrm{v} 117 / \mathrm{i} 4 / 597-605$ 